\title{
Stratigraphy of the Roraima Supergroup along the Brazil-Guyana border in the Guiana shield, Northern Amazonian Craton - results of the Brazil-Guyana Geology and Geodiversity Mapping Project
}

Estratigrafia do Supergrupo Roraima ao longo da fronteira Brasil-Guiana no escudo das Guianas, norte do Cráton Amazônico - Resultados do Projeto Mapeamento Geológico e da Geodiversidade Brasil-Guiana

\section{Nelson Joaquim Reis ${ }^{1 *}$, Serge Nadeau ${ }^{2}$, Leda Maria Fraga ${ }^{1}$, Leandro Menezes Betiollo르. Maria Telma Lins Faraco ${ }^{1}$, Jimmy Reece ${ }^{2}$, Deokumar Lachhman ${ }^{2}$, Randy Ault ${ }^{2}$}

\begin{abstract}
The Geological and Geodiversity Mapping binational program along the Brazil-Guyana border zone allowed reviewing and integrating the stratigraphy and nomenclature of the Roraima Supergroup along the Pakaraima Sedimentary Block present in northeastern Brazil and western Guyana. The area mapped corresponds to a buffer zone of approximately $25 \mathrm{~km}$ in width on both sides of the border, of a region extending along the Maú-Ireng River between Mount Roraima (the triple-border region) and Mutum Village in Brazil and Monkey Mountain in Guyana. The south border of the Roraima basin is overlain exclusively by effusive and volcaniclastic rocks of the Surumu Group of Brazil and its correlated equivalent the Burro-Burro Group of Guyana.

KEYWORDS: Roraima Supergroup; Brazil-Guyana border; stratigraphy.
\end{abstract}

RESUMO: O programa binacional de Mapeamento Geológico e da Geodiversidade na fronteira Brasil-Güiana possibilitou a revisão e integração da nomenclatura estratigráfica do Supergrupo Roraima ao longo do Bloco Pacaraima nas regioes extremo norte brasileira e ocidental guianense. A área corresponde a um buffer de aproximados 25 quilômetros a partir da fronteira, em um trecho definido pelo Monte Roraima (região de tríplice fronteira) e vizinhanças da vila Mutum, no Brasil, e serra Monkey, na Guiana, ao longo do rio Maú ou Ireng. O flanco sul da bacia assenta exclusivamente em rochas efusivas e vulcanoclásticas dos correlatos grupos Surumu e Burro-Burro.

PALAVRAS-CHAVE: Supergrupo Roraima; Fronteira Brasil-Guiana; estratigrafia.

${ }^{1}$ Serviço Geológico do Brasil - Superintendência Regional de Manaus - Manaus (AM),Brazil. E-mails: nelson.reis@cprm.gov.br; leda.fraga@cprm.gov.br; leandro.betiollo@cprm.gov.br; telma.faraco@cprm.gov.br

${ }^{2}$ Guyana Geology and Mines Commission (GGMC) - Georgetown, Guiana. E-mails: goldenserge@hotmail.com; jimmy@ggmc.gov.gy; deokumar_lachhman@yahoo.com; randy_alt07@yahoo.com

*Corresponding author.

Manuscript ID: 20160139. Received in: 12/09/2016. Approved in: 02/03/2017. 


\section{INTRODUCTION}

The Pakaraima Sedimentary Block (PSB) (Reis \& Carvalho 1996, Reis \& Yánez 2001) represents a stratigraphical landmark of the Roraima Supergroup, being the register of a Paleoproterozoic sedimentary basin in the northern portion of the Amazon Craton (Fig. 1). Of unparalleled scenic beauty, it gathers a dozen tepuys, which stand out Mount Roraima, a triple frontier between Brazil, Venezuela and Guyana (Reis 2009). The basin register a historical gold and diamond mining activity in a stratigraphic framework poorly investigated and deserving attention at the application of sequence stratigraphy, tectonic setting and geochronological studies.

This paper discusses the correlation of the stratigraphy of the Roraima Supergroup on both sides of the border of Brazil with Guyana, based on the work performed during the Geological and Geodiversity (land-use) Mapping of the Brazil-Guyana Project, carried out by geologists of the CPRM - Geological Survey of Brazil and the GGMC Guyana Geology and Mines Commission. The area of geological mapping includes the three main villages of Uiramutá and Mutum on the Brazilian side and Orinduik on the Guianese side, all of them located within that buffer zone of 25 kilometers on both sides of the frontier (Fig. 2). In spite of the bad weather conditions and the impossibility to drive along the dirt roads between Karasabai Village and Monkey Mountains, it was possible to reach Orinduik by plane. During the flight, it was possible to observe an interesting area of the Roraima Supergroup where the first sedimentary rocks form cliffs overlying the Iwokrama volcanics

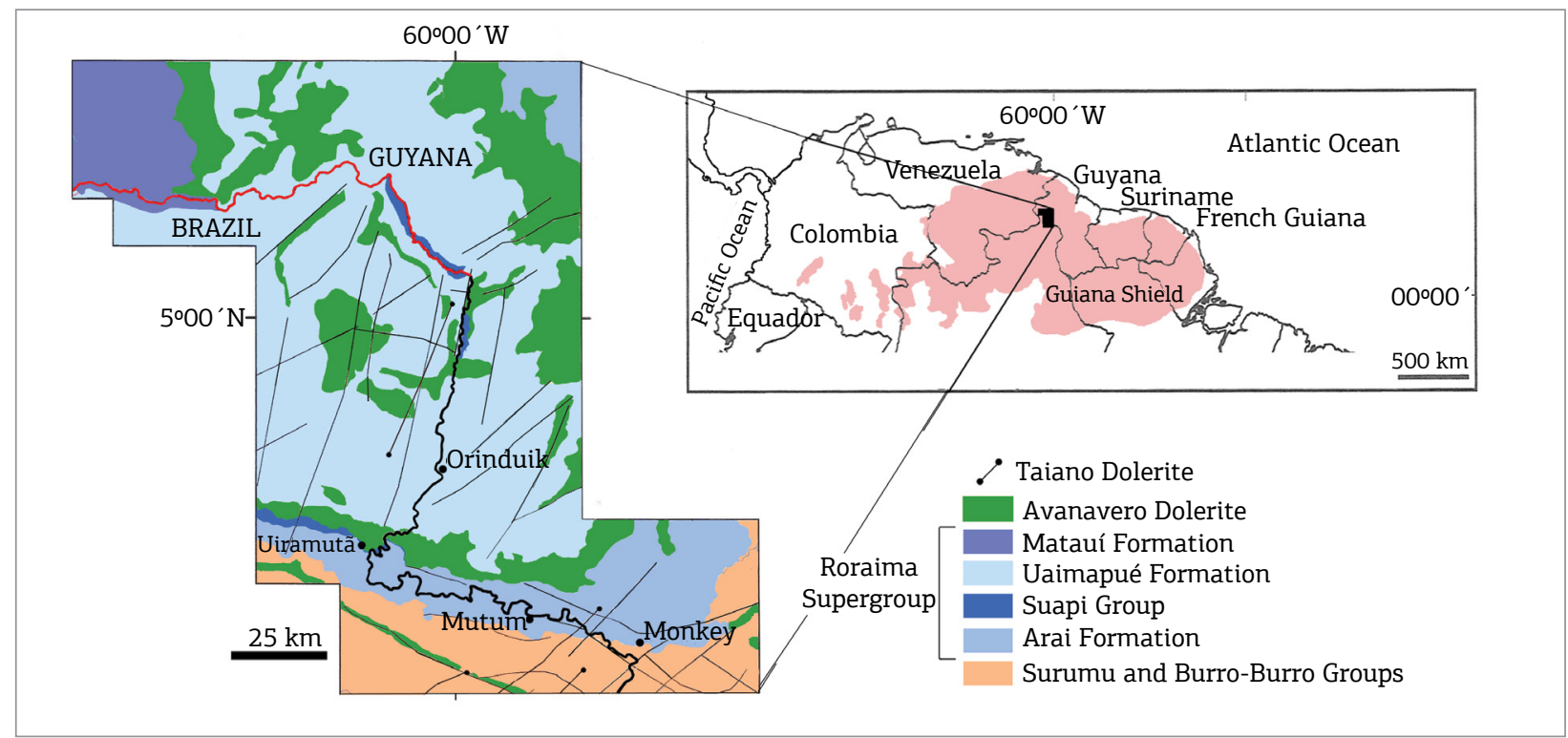

Figure 1. The PSB along the Venezuela, Brazil and Guyana border and the regional geological setting of the Guiana Shield.

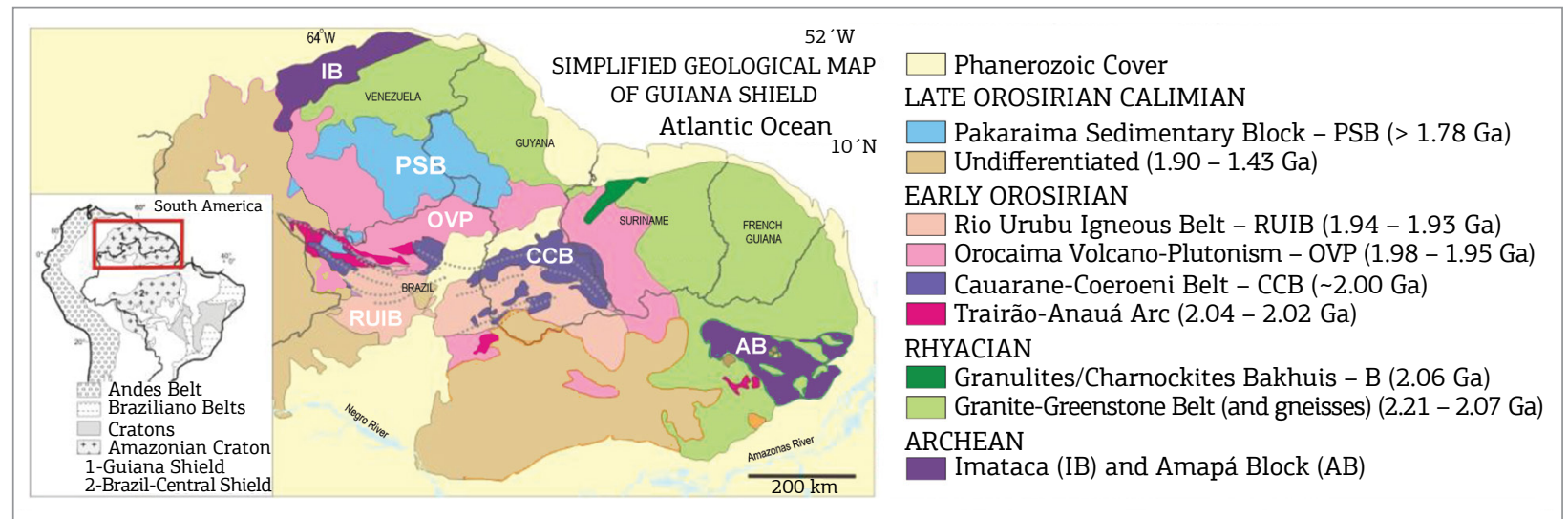

Figure 2. Simplified geological map of the Pakaraima Sedimentary Block along the Brazil and Guyana border and the location of the Guiana Shield, north of the Amazon Craton. 
and where tuffs of the Uaimapué Formation are forming hills and plateaus. Another landscape feature observed was the rainforest distribution developed over the hills of basic rocks, occurring as dyke and sill intrusions of the Avanavero Dolerite. The interpretation of the landscape was an important tool to identify the units of the Roraima Supergroup in Guyana, once the stratigraphy has been defined by previous and detailed mapping work on the Brazilian side.

\section{REGIONAL GEOLOGICAL SETTING}

The Roraima Supergroup is part of the Pakaraima Sedimentary Block, forming a continuous area of sedimentary rocks covering some $73,000 \mathrm{~km}^{2}$ of the Guiana Shield in parts of Venezuela, Brazil and Guyana (Fig. 1). Using the geochronological provinces subdivisions defined by Tassinari and Macambira (2004), the PSB will be part of the Maroní-Itacaiúnas Province with ages ranging between 2.2 and $1.9 \mathrm{Ga}$. On the other hand, it will belong to the Tapajós-Parima Province proposed by Santos et al. (2006), with ages varying between 2.03 and $1.88 \mathrm{Ga}$.

The Roraima Supergroup, whose sediments have been deposited throughout the Orosirian period of the Paleoproterozoic Era, has maximum and minimum ages of 1.95 and 1.78 billion years, respectively (Tab. 1). Zircons from tuffs within the Uaimapué Formation yielded a U-Pb SHRIMP age of $1873 \pm 3 \mathrm{Ma}$ (Santos et al. 2003). The minimum age of the Roraima Supergroup is $1795 \pm 2 \mathrm{Ma}$ and $1782 \pm 3 \mathrm{Ma}$ and was determined by U-Pb geochronology using baddeleyite and zircon from two mafic sills (Avanavero magmatism) possibly suggesting two pulses of magmatism during the Avanavero event (Santos et al. 2003, Reis et al. 2013). The main sources of sediments of the Arai Formation were rocks of Trans-Amazonian age $(2.26-2.01 \mathrm{Ga})$, as indicated by the main population of detrital zircons at $2123 \pm 14 \mathrm{Ma}$. The second source was rocks with an age of $1958 \pm 19 \mathrm{Ma}$ (Santos et al. 2003), probably related to the Orocaima Event which included Surumu calc-alkaline volcanic rocks and its plutonic equivalents of the Pedra Pintada Suite granitoids (Reis et al. 2000a) and from Iwokrama volcanic rocks and its plutonic equivalents.

The Roraima basin along the southern border of the PSB unconformably overlies volcanic rocks of the Surumu Group and Iwokrama Formation (Burro-Burro Group) in the Brazilian and Guyanese terranes, respectively, forming an elongated E-W trending belt. These rocks show a prominent mylonitic foliation, which has been attributed to the regional deformation of the crust during the K'Mudku episode around 1.2 Ga. No contacts were observed between the sedimentary rocks of the Roraima Supergroup with the comagmatic granitoids of the volcanic rocks of the Surumu and Burro-Burro Groups. At the base of the Roraima Supergroup, where the sedimentary rocks were locally tightly to gently folded, they only present traces of low-grade metamorphism in the zeolite facies. Thermal metamorphism is always present along the contact of the Avanavero intrusive bodies (Pinheiro et al. 1990). Swarm of dolerite dykes dated at around $200 \mathrm{Ma}$ (Nomade et al. 2007) cut all of these older rocks, mainly in a NE-SW direction, extending over more than $70 \mathrm{~km}$ for the Tumong Dyke located near the Brazil-Guyana border, to the southeast of Orinduik village.

Table 1. Stratigraphy of Roraima Supergroup proposed by Reis and Yánez (2001) along the Brazil - Venezuela border and it extension to Guyana. Compilation of ages of the volcanic rocks underlying the Roraima Supergroup along the border between Brazil and Guyana (Surumu Group and Iwokrama Formation), of a pyroclastic rock unit of the Uaimapué Formation in Brazil and of intruding sills of the Avanavero Dolerite in Brazil.

\begin{tabular}{|c|c|c|c|c|}
\hline \multicolumn{3}{|c|}{$\begin{array}{l}\text { Brazil-Venezuela Stratigraphy as proposed } \\
\text { by Reis and Yanez (2001) }\end{array}$} & Keats (1973) & \multirow{2}{*}{$\begin{array}{c}\text { Main U-Pb and Pb-Pb Ages } \\
{ }^{1} 1787 \pm 14(\mathrm{bd}) ;{ }^{1} 1782 \pm 3(\mathrm{zr}) ;{ }^{2} 1795 \pm 2(\mathrm{bd})\end{array}$} \\
\hline \multirow{10}{*}{ 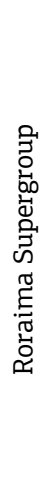 } & \multicolumn{3}{|c|}{ Avanavero Magmatism } & \\
\hline & Matauí Formation & & Unit X & \\
\hline & Uaimapué Formation & & Unit IX & ${ }^{1} 1873 \pm 3 \mathrm{Ma}$ \\
\hline & \multirow{5}{*}{ Suapi Group } & Quinô Formation & Unit VII and VIII & \\
\hline & & Cuquenán Formation & Unit VI & \\
\hline & & Pauré Formation & \multirow{3}{*}{ Unit V } & \\
\hline & & Verde Formation & & \\
\hline & & Uiramutã Formation & & \\
\hline & Arai Formation & & Unitn I to IV & ${ }^{1}$ detrital zircons: $2123 \pm 14$ (main); $1958 \pm 19$ (younger) \\
\hline & \multicolumn{2}{|c|}{ Pakaraima/Surumu Group } & Iwokrama Fm. & ${ }^{1} 1984 \pm 9 ;{ }^{3} 1989 \pm 10 ;{ }^{4} 1966 \pm 7 ;{ }^{4} 1964 \pm 7 ;{ }^{5} 1982 \pm 3$ \\
\hline
\end{tabular}

References: ${ }^{1}$ Santos et al. (2003); ${ }^{2}$ Reis et al. (2013); ${ }^{3}$ Nadeau (not publ.); ${ }^{4} \mathrm{CPRM}$ (2016) in press; ${ }^{5} \mathrm{CPRM}$ (2010). (bd) baddeleyite; (zr) zircon 
The Roraima basin is interpreted as a rift-sag setting formed during an extensional tectonic phase in which N-S general event was responsible for the development of normal E-W faults and transfer faults. It forms an asymmetrical basin of rhombohedric geometry controlled by NW-SE faults. Later, during the $\mathrm{K}^{\prime} \mathrm{Mudku}$ episode times, the basin experienced a weak positive inversion involving the reactivation of normal upthrow faults and the transfer faults as lateral ramps. At the southern border of the basin, in proximity to the E-W faults, the rocks of the Roraima Supergroup occur in echelon folds, however, towards the centre of the basin, no deformation of its rock units is recorded, which led to the preservation of its primary stratigraphic relationships (Pinheiro et al. 1990).

Much of the Roraima sedimentary rocks occur within the PSB, although it can be traced over large areas of Venezuela, Brazil, Guyana and Suriname, as suggested by the presence of outliers at Urutanim, Uafaranda, Tepequém, Makari and Tafelberg. However some of these table mountains are believed to be Roraima-like and overlay volcanic rocks with ages $100 \mathrm{Myr}$ younger than those of the Surumu and Burro-Burro Groups, as for the Urupi basin in the northeast portion of the Amazonas State. In the same way, the Neblina and Padre Mountains (northwest of the Amazonas State) overlies a basement much younger than the Roraima Supergroup. The Surucucus Formation (northwest of the Roraima State) has a post-Parguaza age and contains a younger population of clastic zircons at $1551 \pm 5 \mathrm{Ma}$ (Reis et al. 2000b). Therefore, these overlying sedimentary outliers present distinct stratigraphy which appear diachronous to the tectonic history of the PSB and some revision of these ten type-localities is needed before attempting to correlate them, as was pointed out by Reis and Carvalho (1996).

\section{THE RORAIMA SUPERGROUP - SOME MAIN ADVANCES}

The sedimentary cover consists of a thick succession of about 2,770 meters of siliciclastic, pyroclastic and volcaniclastic rocks whose stratigraphy was investigated over six decades by many geoscientists including Bouman (1959), Reid (1972), Yánez (1972; 1977), Keats (1973), Gansser (1974), Ghosh (1981), Reis et al. (1985; 1988; 1990), Santos (1985), Castro and Barrocas (1986), Barron (1986), Pinheiro et al. (1990), Reis and Yánez (2001), Wankler (2001), Long (2002), Santos et al. (2003), Minter (2009) and Beyer et al. (2015), among others.

In Brazil, Bouman (1959) subdivided the Roraima Formation into three members, with reference to the Arai Mountain region. Reid (1972) was the first to make a detailed stratigraphy of the rocks into four formations that were grouped under the term "Roraima Group" in the Santa
Elena de Uairén area, southeast Venezuela. In Guyana, Keats (1973) defined nine distinctive sedimentary Units (I to IX) of the Roraima sedimentary cover and discussed the environment of deposition, although he made no correlation attempts with Reid's stratigraphy in Venezuela.

Ghosh (1981) suggested that some sedimentary outliers of fluvial-deltaic to coastal and marine environments of the Sipapu and Paru "cerros" located to the west of the PSB in the Amazonas State of Brazil and in Venezuela were not related to the Roraima's stratigraphy proposed by Reid (1972) at Santa Elena de Uairén. In Brazil, Santos and D’Antona (1984) proposed a subdivision of the group defined by the work of Reid (1972), into five formations (from bottom to top: Arai, Suapi, Quinô, Uailã and Matauí). Later work by Reis et al. (1985) in the Quinô River area proposed to subdivide the Suapi Formation into four members (from bottom to top: Verde, Pauré, Carmã and Nicarã). The Suapi Formation was observed to be in unconformity with the Arai Formation and overlain by the Quinô Formation, although the latter contact was not seen in the field. More recently, Reis et al. (1988) introduced the term Suapi Group which included in order from botttom up the Verde, Pauré, Nicarã and Quinô Formations which was made subsequently to the status change of the Roraima proposed by Pinheiro et al. (1990) from Group to Supergroup and to the detailed description of its environment of deposition by Castro and Barrocas (1986).

During the nineties, Reis et al. (1990) showed that the Arai Formation presented characteristics typical of a continental sedimentary facies, in contrast to the transitional facies proposed by Pinheiro et al. (1990) based on observations in the Upper Member of the Formation. The Serra do Sol Formation that was proposed by Santos (1985) was rejected by the latter authors. The first integrated stratigraphy correlation between Brazil and Venezuela of the Roraima sedimentary cover was developed by Reis and Yánez (2001) who proposed from the bottom and upwards: The Arai Formation, followed by the Suapi Group (Uiramutá, Verde, Pauré, Cuquenán, and Quinô Formations), the Uaimapué Formation and the Matauí Formation. These latter authors also abandoned the use of the terms "Nicarâ" and "Uailâ" and rather introduced the term "Uiramutã (Tab. 2; Fig. 3).

\section{THE STRATIGRAPHY OF THE RORAIMA SUPERGROUP - IMPLICATIONS FOR GUYANA}

The stratigraphy of the Roraima Supergroup was defined by their respective depositional environments (from base to top):

Arai Formation - The volcanic rocks of the Surumu Group are uncomformably overlain by sandstones, 
conglomeratic sandstones, conglomerates and mudstones of continental source (Reis et al. 1990). It displays characteristic features typical of alluvial fan, lacustrine, aeolian sand bodies and braided fluvial facies. Among the various levels of conglomerates of the Roraima Supergroup only those of the Arai Formation representing braided fluvial environments are economically important since gold and diamonds were mined by pork-knockers in areas of Venezuela, Brazil and Guyana. However, the main source of alluvial gold and diamonds mined on the Brazilian side of the Roraima Basin are the paleoterraces derived from the erosion of the conglomerates of the Arai Formation. These paleoterraces of Paleogene age belong to the Trincheira Formation of Reis and Pinheiro (2004).

A thick layer of intercalated volcaniclastic and volcanic rocks near the base of the Arai Formation has been important to define the basement of the Roraima basin. In the Ichún Tepuy area, southwest Venezuela, Briceño et al. (1989) have described a 2430 meters thick sucession of volcaniclastic and volcanogenic rocks which discordantly overlies the effusive rocks of the Cuchivero Group and transitionally underlies the sedimentary rocks of the Roraima. Brooks and Garcia (1999) have mentioned the Carun circular structure in the Bolivar State, Venezuela, as an intact Proterozoic caldera with a diameter of aproximately $15 \mathrm{~km}$ in the Cuchivero Province. In a similar way, a volcanic caldera model has been proposed for the Tepequém Mountain, a Roraima sedimentary outlier situated at the southwest portion of the PSB (Reis et al. 2009, Dreher et al. 2011). The stratigraphy of the Tepequém Mountain is dominated by volcanic cobbles- and pebbles-bearing fanglomerates related to the caldera walls (named the Tepequém Formation, a pre-Roraima unit)

Table 2. Stratigraphy of the Roraima Supergroup in Brazil and in Venezuela through time as proposed by various authors: 1) Bouman (1959); 2) Yánez (1972, 1977); 3) Reid (1972); 4) Reis et al. (1985); 5) Santos (1985); 6) Reis et al. (1988, 1990); 7) Reis and Yánez (2001); 8) Keats (1973). The correlation between the stratigraphy of the Roraima Supergroup in Brazil and Venezuela with the unit subdivisions in Guyana are shown in the last two columns to the right (this work).

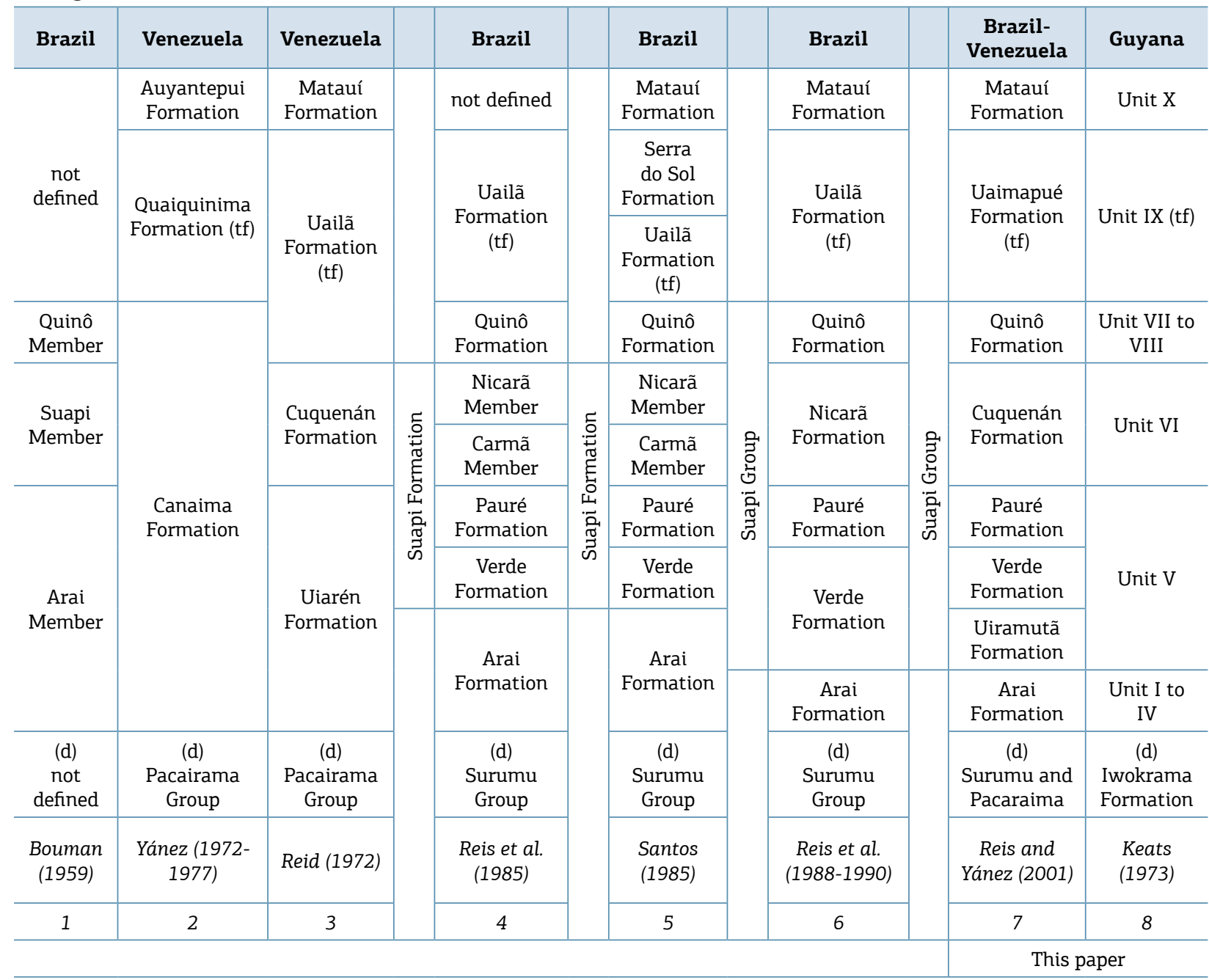

$\mathrm{Br}$ - Brazil; Vz - Venezuela; Gu - Guyana 
and by quartz pebbles-bearing conglomerates similar to those of the Arai Formation, in turn overlying those volcanogenic rocks.

Close to the border with Guyana, in the Paiuá Creek and in the surrounding Lilás Mountain, there is a succession of volcaniclastic rocks adjacent to the basal conglomerates of the Roraima Supergroup. The bottom pyroclastic flow shows a basal layer displaying cross-stratification sets and rare epiclastic fragments (base surge deposit), followed by

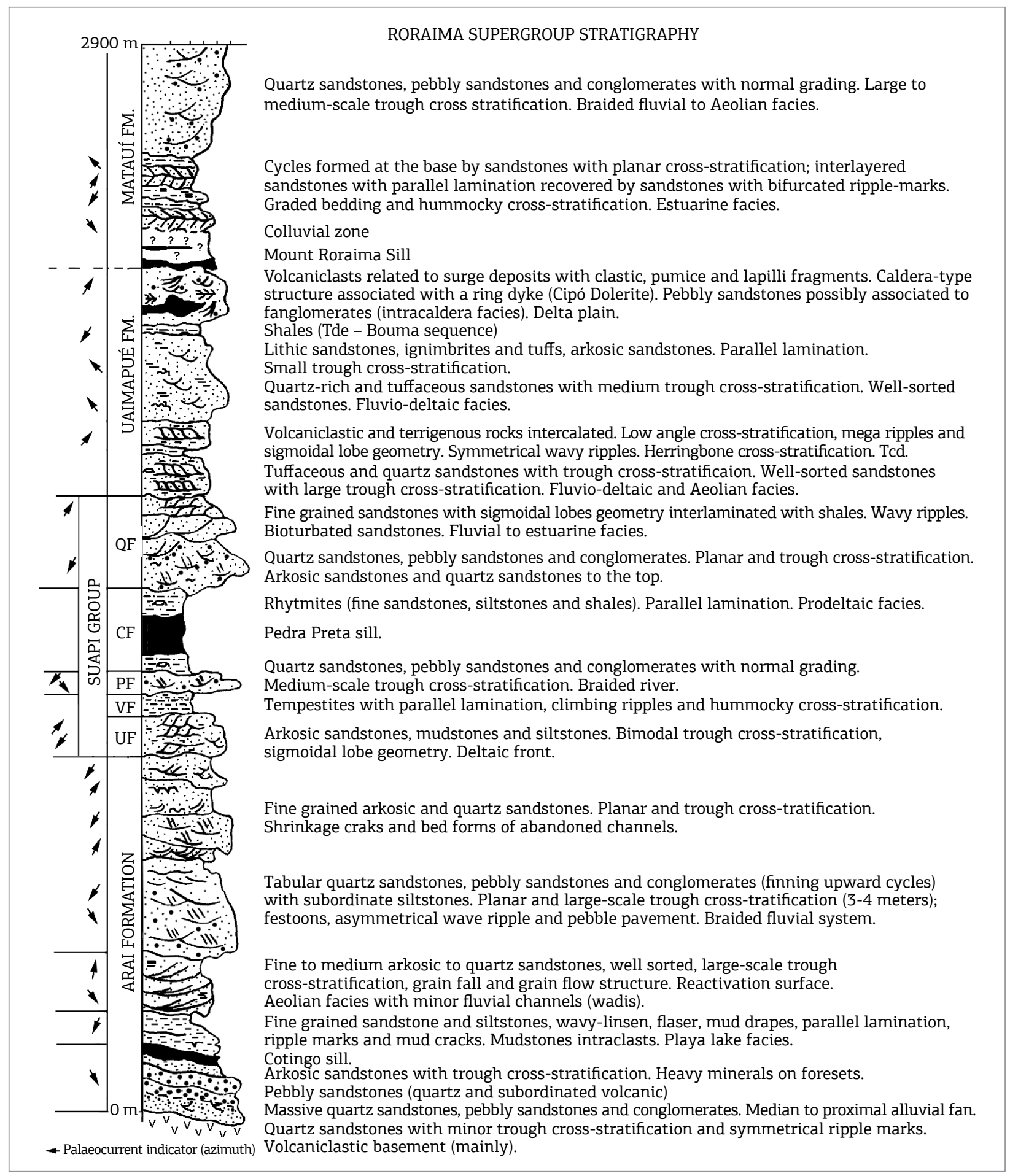

Figure 3. Schematic sedimentary section of the Roraima Supergroup along the Venezuela and Brazil border as proposed by Reis and Yánez (2001): UF) Uiramutã Formation; VF) Verde Formation; PF) Pauré Formation; CF) Cuquenán Formation; QF) Quinô Formation. 
an ash-flow tuff and by ash-fall tuffs containing accretionary lapilli particles towards the top (Fig. 4).

Otherwise, Reid (1972) has described a long hiatus between lava extrusion and earliest sandstones deposition marked by a paleo-relief. However, it lacks a comprehensive description between the volcanic basement and sedimentary or possibly volcanogenic rocks in the Santa Elena de Uairén area, Venezuela, whose outcrops are always weathered.

The Arai Formation extends along the Brazilian border to Guyana following the Maú-Ireng River where it outcrops over a large area which includes Monkey Mountain (Fig. 5).
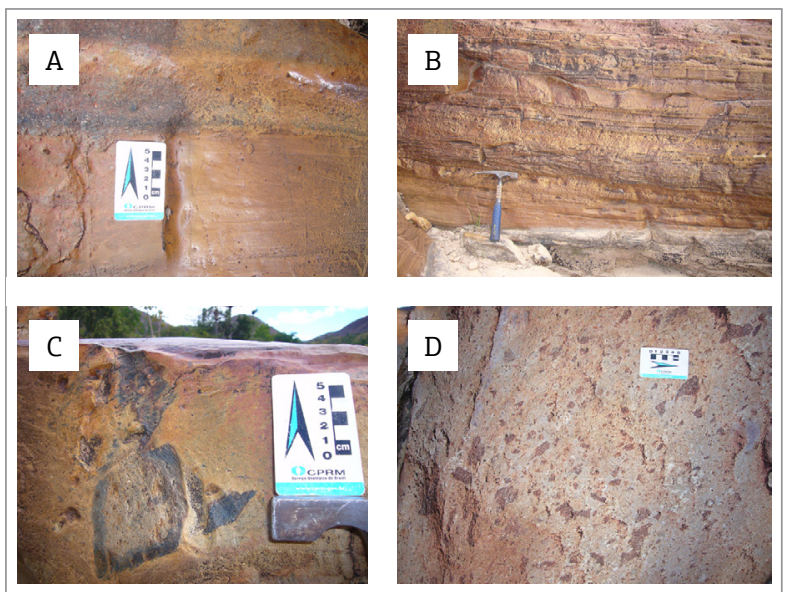

Figure 4. Paiuá Creek. (A) Layer of volcanogenic ferruginous sandstones with small cross-stratifications covered by pyroclastic flows and cineritic deposits (B); (C) and (D) Ignimbrite with pumice fragments.

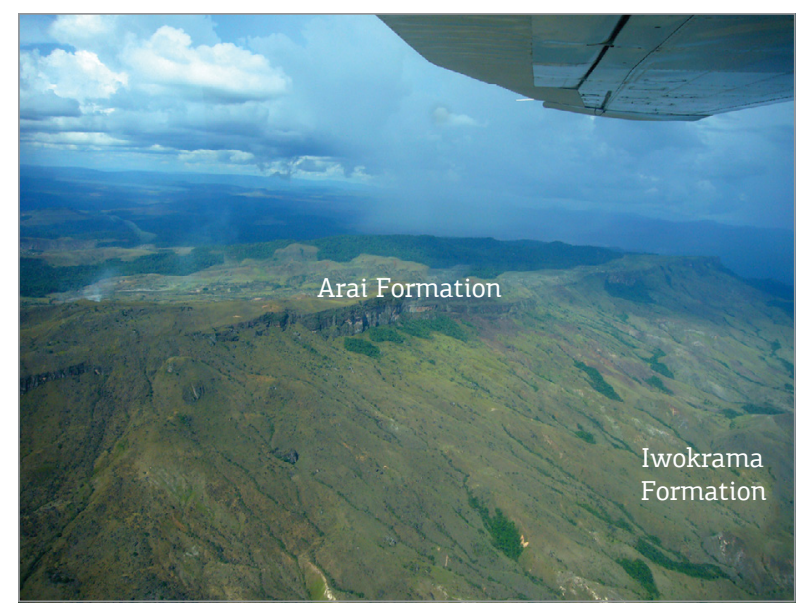

Figure 5. The PSB along the Brazil and Guyana border near Monkey Mountain. In this aerial view, along the southern border of the basin the Iwokrama volcanics are directly correlated with the Surumu volcanics as well as the lower sedimentary rocks of the Arai Formation of the Roraima Supergroup extends continously in both countries.
On the Brazilian side, near Mutum Village, the strata of Arai Formation consist of a folded succession of silicified sandstones and conglomerates.

The folding of rocks along the border appears to be more prominent on the Brazilian side within the Arai Formation. On the Guyanese side Keats (1973) only mentioned tight folding present in the area of the Merume River, where it is believed that the rocks belong to the basal conglomerates of Unit I of the Roraima Supergroup. Tight to open folds were described by Pinheiro et al. (1990) within Rebenque Creek near Mutum Village and at Lilás Mountain on the Brazilian side of the Ireng River (Fig. 6). Shear zones are common and parallel to the east-west axial plane of the folds. As a whole, the pattern of folding is believed to represent asymmetrical drag folds produced by normal faulting during the K'Mudku episode, as described by CPRM (2016) in the Tepequém Mountain, an outlier of the Roraima Supergroup. These shear zones cut through the volcanic rocks resulting into pinnacle-shaped outcrops (Fig. 7). The rocks form prominent hogbacks with steep dips greater than $30^{\circ}$ to the north.

Along the Venezuelan border, in the vicinity of the Santa Elena de Uairén city, the rocks of the Roraima Supergroup were described as consisting predominantly of a gently folded
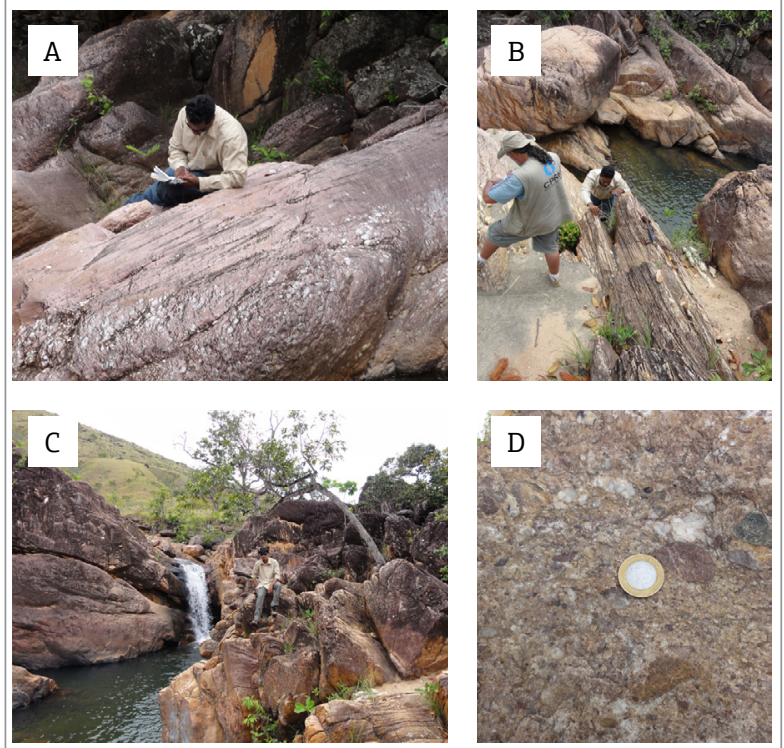

Figure 6. Rebenque Creek in the vicinity of Mutum Village. Limbs of a tight fold dipping to the north (A) and to the south (B) with shear zones occuring parallel to the east-west striking axial plane of the fold. (C) Lilás (Purple) Mountain. Open fold with limbs striking to the north and south; (D) At the foot of Lilás Mountain outcrops of pyroclastic rocks of the Surumu Group as in the Paiuá Creek are mainly composed of lapilli tuffs. The contact between the pyroclastic and terrigenous rocks seems to be gradational and the first 50 meters is mainly of quartz sandstones. 
sequence of fine to very coarse-grained sandstone with subordinate conglomerate and mudstone, in turn, cut by a dolerite sill (Reid 1972, Long 2002). On the Brazilian side at this same level the Cotingo sill intrudes the Surumu volcanics over a large area.

According to Keats (1973), it is difficult to correlate the basal conglomerate layers of the Roraima Supergroup from one area to another, since these conglomerates do not show clear differences in their pebble contents, sometimes with quartz fragments accounting for more than $95 \%$ of the pebbles.

The bulk of the first 150 meters of the Arai Formation is only estimated in the south of Uiramutã Village and in the Mutum Gorge, since tectonic events have modified the topography of Lilás Mountain and the area of Mutum Village. At these localities the conglomerates are massive (no apparent internal structure), well-sorted with a clast supported framework of pebbles of quartz and lesser amounts of volcanic fragments. They are interbedded with massive medium- and fine-grained pebble sandstones which grade to quartz sandstones containing trough cross-stratifications and planar bedded sandstones.

Although the main lithologies of the Arai Formation in the Brazil-Guyana border area are similar, neither Keats (1973) nor Barron (1986) described aeolian sandstones and lacustrine mudstones and siltstones like those mentioned by Reis et al. (1990). It is possible that the outcrops on the Guyanese side are not well exposed if they are composed of fine-grained sedimentary rocks more susceptible to erosion by weathering. However, more recent drilling and detailed stratigraphy work by Minter (2009) and Beyer et al. (2015) on the easternmost side of the Roraima Supergroup in Guyana had identified sandstones of aeolian origin and mudstones representing lake conditions that probably extended towards the western side of

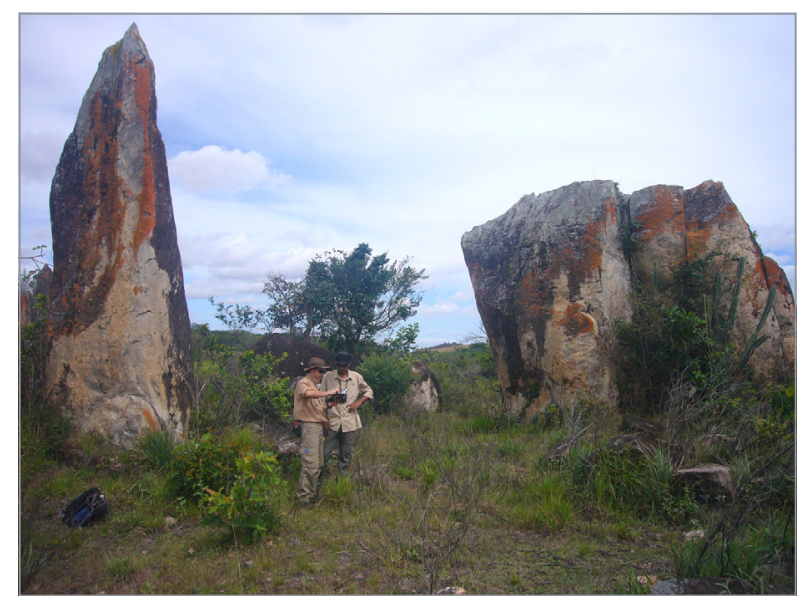

Figure 7. Gravel road to Mutum Village. Shear zones cutting the pyroclastic rocks of the Surumu Group resulted in the formation of pinnacles with prominent foliation striking E-W with down-dip lineation.
Guyana and the Brazil-Guyana border area. Ten formations were described by Minter (2009) with major time breaks, in turn, correlated with the first five units defined by Keats (1973). In the same area, Beyer et al. (2015) described two lithofacies associations identified by major erosional bounding surfaces, the upper representing lakes and subaerial flats. The Arai Formation of the Roraima Supergroup in Venezuela near Santa Elena de Uairén, was also described as containing thick mudstones representing deposits of temporary lakes under arid climatic settings (Long 2002).

Those lacustrine mudstones and aeolian arkosic sandstones in Brazil appear in the vicinity of the gravel road to Uiramutã Village and are shown in Figs. 8 and 9, respectively.

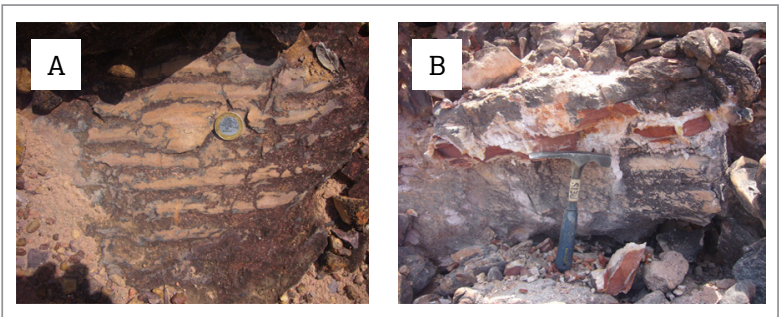

Figure 8. Gravel road to Uiramutã Village. (A) Symmetrical ripple-marks (lower flow regime) at the top of sets of compact and reddish mudstones interpreted as playa-lake deposits associated with the aeolian sandstones of the Arai Formation; (B) Cross-cutting and rythmites intercalation of alternating mudstones and siltstones.
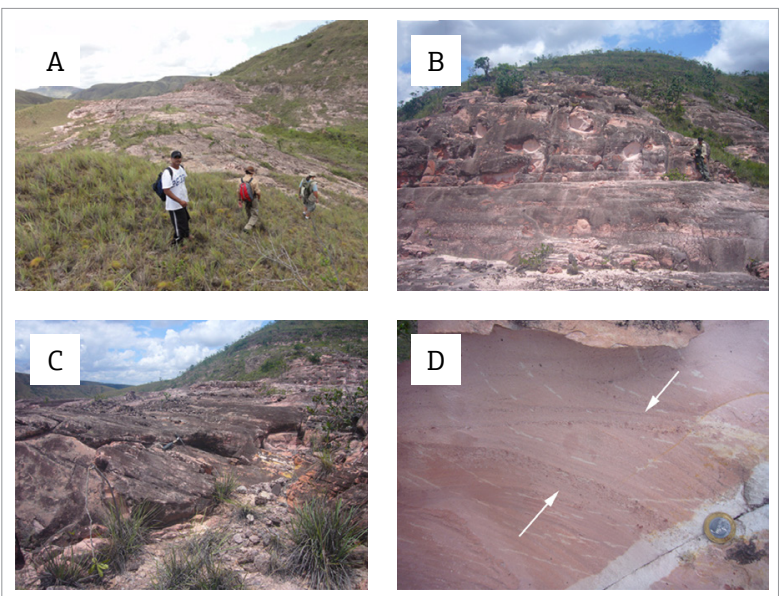

Figure 9. Gravel road to Uiramutã Village (dunes field). (A) Fine and friable pinkish arkosic sandstones interpreted as aeolian dunes; (B) Reactivation surface between sets of large-scale trough cross-stratifications; (C) View of a major trough displaying cross-stratification with palaeocurrent flow direction to the NE; (D) Grain fall and grain flow structures present in the arkosic sandstones, very common in aeolian settings by grain avalanches on the slip faces of sand dunes (see arrows and coin for scale). 
They were firstly described by Castro and Barrocas (1986) and Pinheiro et al. (1990). These rocks overlain quartz sandstones and conglomerates of the Arai Formation and are believed to be deposited in a more distal position of an alluvial fan.

The lacustrine siltstones and mudstones are interbedded with intraformational conglomerates in which the ripplemark cosets contain pelite intraclasts. They are interpreted to correspond to lacustrine turbiditic sequences. Symmetrical ripple marks and mud-cracks are common at the top of the thin sets of beds forming a network of structures in outcrops of the Suapi River (Pinheiro et al. 1990).

Pinkish arkosic sandstones are fine- to medium grained, well-sorted and form thick layers with large-scale trough cross-stratification. Reactivation surfaces separate the sets of these cross-stratifications. The cross-sets become progressively flatter and thinner at the top of the dunes. Internal structures of grain size grading and grain flow direction are observed. These sedimentary rocks contrast with quartz sandstones forming more pink to whitish color rounded hills on the side of valleys. To the top of the aeolian bed sequences corresponding to dune sandbars they appear to be cut by braided fluvial deposits which were also in turn covered by additional sand dune deposits.

It is concluded that a regional unconformity is present between the lower lacustrine mudstones, siltstones and aeolian arkosic sandstones with the upper conglomerates and quartz sandstones. Fragments of silicified sandstones into fine to medium arkosic sandstones are believed to have been carried by temporary streams (wadis).

Towards the upper part of the Arai Formation there is a thick succession of quartz-rich sandstones, pebbly sandstones and conglomerates interbedded in a fining upwards cycles. It is interpreted in terms of deposition in a fluvial environment composed of braided rivers. The pebbly sandstones were dominantly deposited as channel sand bars and large-scale trough cross-stratifications (Fig. 10). Paleocurrent measurements trend to the SW indicating sourcing is from the northeast (Reis et al. 1990).

In this paper, Units I to IV of Keats (1973) can be correlated with the Arai Formation based on several common features:

- A common deposition environment and history starting from the correlation of the basement rocks of the Surumu and Iwokrama rocks in Brazil and Guyana, respectively. The main sources of sediments of the Arai Formation were rocks of Trans-Amazonian age showing common sources from the greenstone belts in the northernmost portion of Guyana and Venezuela;

- Conglomerates, pebbly sandstones and arkosic sandstones displaying fining upwards fluvial cycles;
Large river channel deposits with large-scale trough cross-beds and unimodal palaeocurrent distributions to the southwest (Fig. 11);

- Vertical and lateral facies associations, sand-body geometry and mainly by their lithofacies;

- Similar physiography of the terrigenous sedimentary rocks of the Arai Formation on the Brazilian side of the border area and extension to the Guyanese side, forming cliffs where quartz-rich sandstones and conglomerates are well-preserved in relation to the arkosic sandstones;

- It is also possible to correlate the lithostratigraphy of the Merume, Potaro, Karanang and Monkey Mountain areas in Guyana with those from Mutum and Uiramutã areas on the Brazilian side;

- There is also similarities in the main features of the environment of depositions in Brazil, Guyana and Venezuela. Keats (1973) had described a proximal to distal fluvio-deltaic depositional environment for Units I to IV. On the Brazilian side within the Arai Formation, Reis et al. (1990) were able to define four sedimentary facies: alluvial fan, braided fluvial, aeolian dunes and playa-lake. On the Venezuelan side, Long (2002) subdivided the Uairén Formation into two members [redefined by Reis and Yánez (2001) as corresponding to the Arai Formation in Brazil] based on the presence of conglomeratic marker beds. Both members were interpreted in terms of deposition in braided rivers or amalgamated braidplains in arid to semi-humid climate
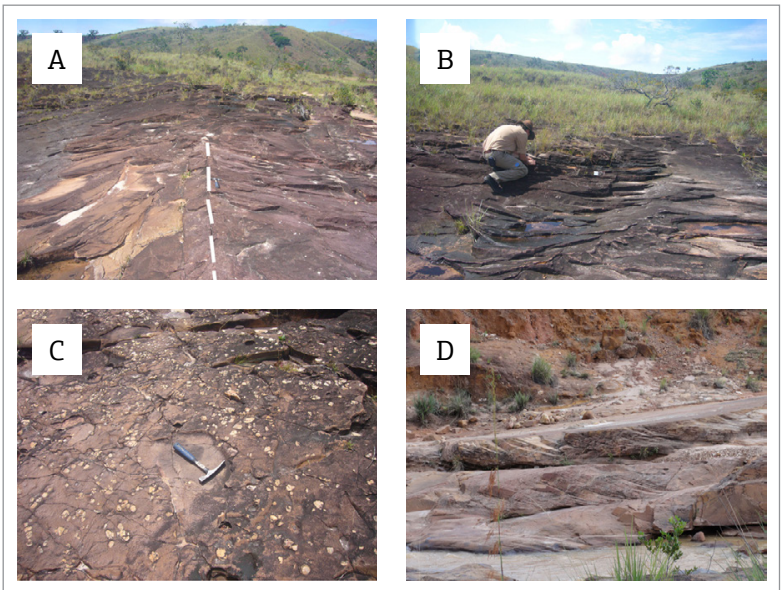

Figure 10. Paiuá Creek. (A) Rib-and-Furrow sedimentary structures in quartz sandstone of the Arai Formation (see hammer for scale); (B) sets of large-scale trough cross-stratifications with palaeocurrent flows direction to the SW. Parting-step lineations are common and plane-bed reflects an upper-flow regime transport of grains; (C) pebbly sandstone with well-rounded quartz pebbles; (D) cosets of trough cross-stratifications corresponding to fluvial conditions of sedimentation of the Arai Formation. 
settings. The thicker mudstones, cited by Long (2002) may represent deposits of temporary lakes or according to Reis et al. (1990) and Pinheiro et al. (1990) corresponding to playa-lakes associated with aeolian deposits.

\section{Suapi Group}

The Suapi Group lies unconformably on top of the Arai Formation and was subdivided by Reis and Yánez (2001) into five formations (bottom to the top): Uiramutâ, Verde, Pauré, Cuquenán and Quinô. On the basis of lithologies and depositional environments variations, the Roraima basin reflects repeated sea level changes. The Suapi Group represents the first sea level changes of the regional patterns of deposition in the basin (regressive-transgressive cycles) and the history of sedimentary successions related to a fluvial-deltaic environment to shallow marine settings. Its formations reflect a great period of subsidence and uplift of the basin.

\section{Uiramutá Formation}

This formation was originally defined by Reis and Yánez (2001) at the Uiramutã Creek near Uiramutã Village, and is considered to have been deposited on a deltaic plain (deltaic front setting). It registers a paleo-environmental inversion at first from a fluvio-deltaic to a tidal plain environments overlying the top of the Arai Formation. It is composed of fine to medium coarse arkosic sandstones, quartz-rich sandstones and subordinate siltstones and mudstones. It shows bimodal palaeocurrent distributions of trough cross-stratification (palaeocurrents to the NE and SW) and sand body geometry of sigmoidal lobes. Mudstones are subordinated to the quartz-rich sandstones, where they form centimetre layers at the top of each sandstone layers. In some places dish structures may represent subaqueous sediment-gravity-flow deposits. There are some tidal flat characteristics of overlying sediments. It can be compared to the Unit V of Keats (1973) where abundant layers of quartz-rich and arkosic sandstones were recognized. This author had concluded that they reflect a proximal fluvio-deltaic to delta front or an intertidal environment. According to Reis and Yánez (2001) the Uiramutã Formation corresponds to the "flooding" of the fluvial system of the Arai Formation by tidal currents. Wankler et al. (2003) have interpreted the Arai and Uiramutã formations as late lowstand systems tracts limited by a transgressive systems tracts represented by the Verde Formation.

\section{Verde Formation}

The Cross Hill area near Uiramutá Village was a good place to define the sedimentary succession of the Suapi Group (Fig. 12A). Rounded hills and cuestas characterize the landscape. The Verde Formation overlays the Uiramutá Formation in an apparent unconformity and is represented by a rhythmical succession of reddish mudstones and siltstones with layers dip of $18^{\circ}$

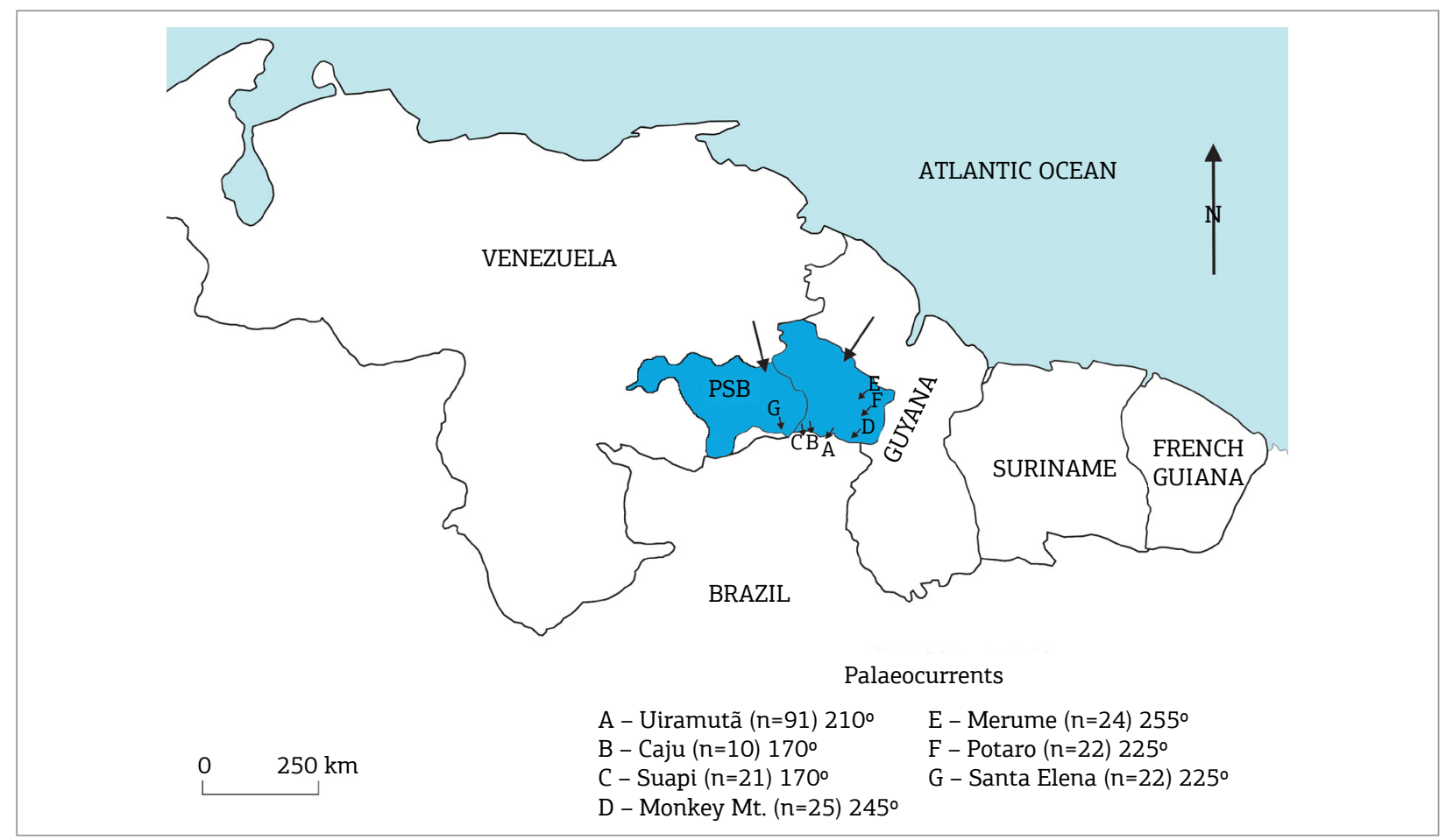

Figure 11. Arai Formation paleocurrents measurement numbers ( $n$ ) and associated azimuth (vector of paleoflow mean direction): A,B,C from Pinheiro et al. (1990); D,E from Keats (1973) and F,G from Ghosh (1981). 
to $12^{\circ} \mathrm{NE}$ (Fig. 12B). These fine-grained rocks show internal structures of parallel lamination, small-scale cross-stratification, climbing ripples cross lamination and microhummocky structures. Castro and Barrocas (1986) had proposed they represent an environment of deposition of an epicontinental sea affected by storm waves (prodelta). Normal grading is characteristic of turbidity-current deposits in the case of Verde Formation. It corresponds to the Bouma's C-D sequence where turbidites are formed in an upper energy regime and must represent deposition from progressively slower currents (Walker 1984).

The Verde Formation has a thickness of about 50 meters (Reis et al. 1985) and was included into Unit V of Keats (1973). The outcrops of the Formation are well-preserved in the Brazilian border area, excepted near the border with Venezuela where it occurs as a flat plain topography. To the east towards the Guyanese border it forms high cliffs of quartz and arkosic sandstones overlain by the Pauré Formation, which is also overlain by the siltstones of the Cuquenán Formation.

\section{Pauré Formation}

The Pauré Formation is composed of a succession of medium to coarse sandstones and pebbly sandstones displaying normal grading (finning upward) and trough cross-stratifications of medium-size (Fig. 12C). It has been interpreted as a fluvio-deltaic environment where retrogradation event had occurred. Palaeocurrent measurements also point to the SW direction as observed for the Arai Formation. The geomorphology is characterized by a resistant sandstone layer located between two fine pelitic layers of the upper Cuquenán Formation and the lower Verde Formation, representing a marker unit within the Suapi Group.

The thickness of the formation is about 50 meters according to Reis et al. (1985) and it seems to be continuous on both sides of the border with Venezuela to the West and Guyana to the East. It is also correlated with parts of Unit V of Keats (1973). Reid (1972) did not describe this arenaceous formation on the Venezuelan side, to the northeast of Santa Elena de Uairén. Reis et al. (1985) showed a generalized stratigraphic description of the "Kukuenán" Formation where fine sediments (mainly shales) occured in the Cuquenán River valley. In fact, towards the Brazilian border there is a wide and long valley where high mountain chains extend to the north (Pakaraima Mountains) and are believed to represent rocks of the Uaimapué Formation. In the upper part of the Quinô River on the Brazilian side, the valley seems
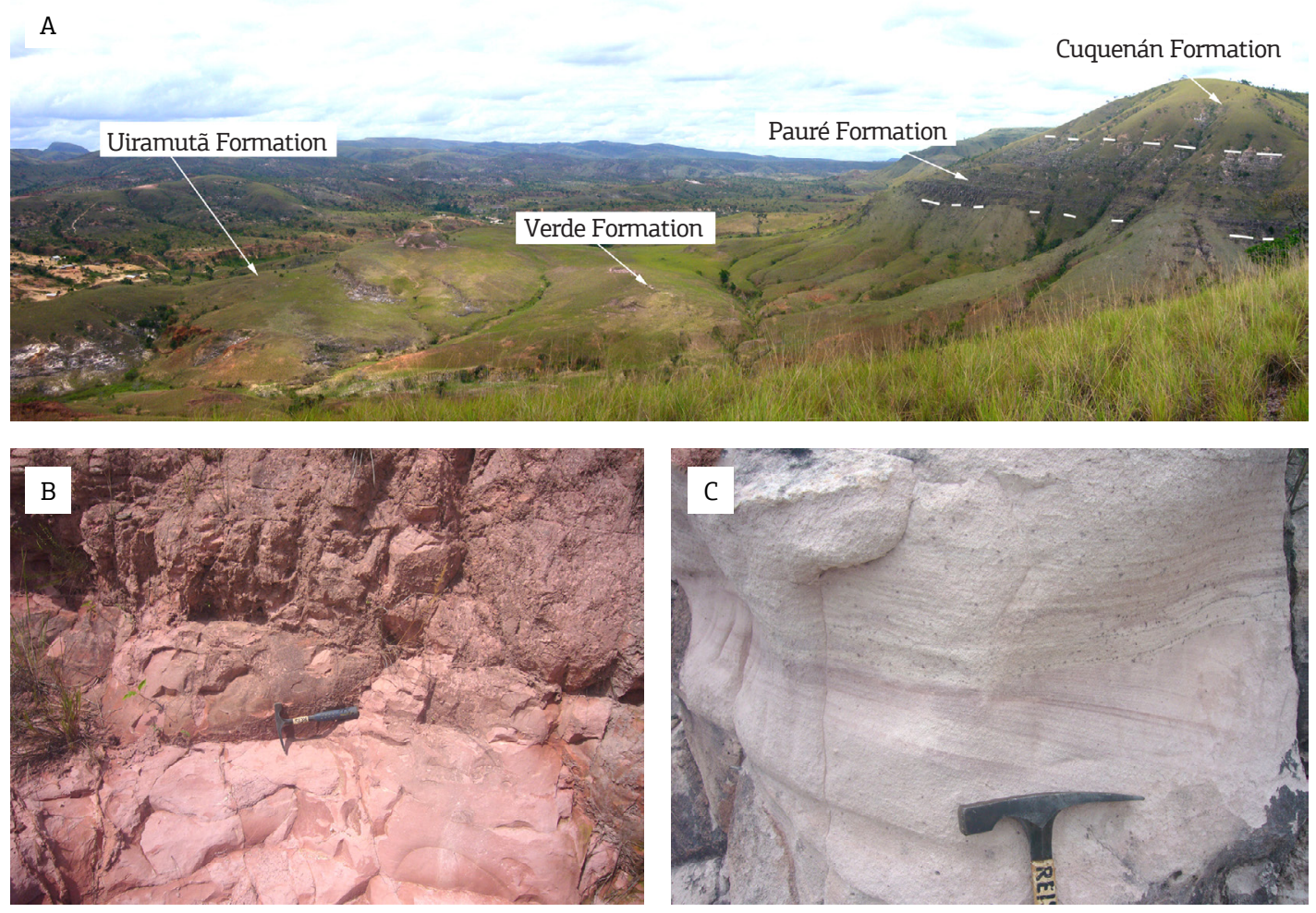

Figure 12. Cross Hill, Uiramutã Village. (A) West of Cross Hill including the four formations of the Suapi Group named Uiramutã, Verde, Pauré and Cuquenán (bottom to top and left to right); (B) fine-laminated reddish siltstones of the Verde Formation; (C) arkosic sandstones to pebbly sandstones with trough cross-stratifications present within the Pauré Formation. 
to form a wide plain where neotectonic movement led to the erosion and lateritic crust formation of the rocks. In this area the Pedra Preta sill — the second highest level of Avanavero rocks within the Roraima Supergroup disappears laterally and does not extend into Venezuela.

\section{Cuquenán Formation}

Greenish-grey shales intercalated with fine-grained sandstones and siltstones with prominent parallel lamination correspond to the Cuquenán Formation (Reid 1972, Reis \& Yánez 2001) which overlies the Pauré Formation. It has been interpreted by Castro and Barrocas (1986) as representing a turbiditic deltaic front with Tdc Bouma cycles. It marks a new transgression phase of the "Verde Sea". This Formation is cut by the Pedra Preta sill which produced hornfels texture along its contact. It can be correlated to Unit VI of Keats (1973) and mapped in many places of Guyana (e.g. Kowa and Kopinang) where the sill corresponds to the Lower Kopinang Sill.

Along the Brazil-Guyana border the sill extends in an area of low relief in contrast to the high mountains present on the Brazilian side suggesting the sill is thinner along the border (Fig. 13).

\section{Quinô Formation}

The type-area of the Quinô Formation was established in the Upper Quinô River along the border with Venezuela (Bouman 1959). It has been described by Pinheiro et al. (1990) as formed by conglomerates, pebbly sandstones, medium- to coarse-fined sandstones and arkosic sandstones. The Quinô Formation overlies the Cuquenán Formation and the contact is always blanketed by talus deposits in high altitude areas (800 metres above sea level). Medium-size (less than 1.0 metre) trough cross-stratifications and tabular cross-stratifications are the most abundant with palaeocurrent directions of the fluvial system to the SW. The top of

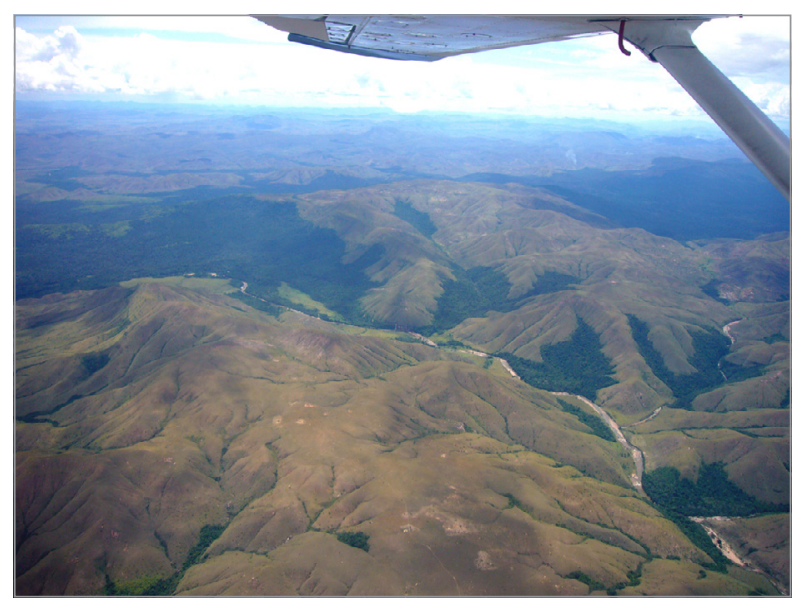

Figure 13. Aerial view of the Guyanese side where broad hills predominate and altered pyroclasts of the Uaimapué Formation have a characteristic pinkish colour. the formation is composed of arkosic sandstones forming layers displaying sigmoidal-shape geometry and palaeocurrent azimuths towards the N, NE and E. Castro and Barrocas (1986) postulated a fluvio-estuarine environment for the Quinô Formation. The upper sedimentary facies of the Quinô Formation (with subordinate shales) constitute a transgressive level with a probable extension into the overlying Uaimapué Formation.

The Quinô Formation can be correlated with Unit VII of Keats (1973) where conglomerates and pebbly sandstones were described in the south of the Pakaraimas, on Tusenen Mountain, near the Kowa River. According to Keats, Unit VII deposition represents a transition (retrogradation) from marine to deltaic environments.

\section{Uaimapué Formation}

The interlayered volcaniclastic, volcanogenic and terrigenous rocks of the Uaimapué Formation represent a fluvial-deltaic (intertidal, shoreline facies) to shallow marine environment. The formation corresponds to a period of volcanism with aerially transported (reddish to greenish ash fall to ash flow acid tuffs) and waterlain and/or reworked volcanic ash (tuffaceous sandstones) that are penecontemporaneous with continuous sedimentation.

The rocks of the Uaimapué Formation grade from those of the underlying Quinô Formation in terms of its depositional environment excepted where the first layers of volcaniclastic rocks were reworked and/or deposited together with the terrigenous layers to represent the Uaimapué Formation. The rocks of this formation include sandstones, lithic sandstones, quartz sandstones, pebbly sandstones and conglomerates as well as ash fall (so-called jasper) and ash flow tuffs, tuffaceous sandstones and breccias. The bedding is dipping approximately $5^{\circ} \mathrm{NE}$ and the maximum thickness of the Uaimapué Formation was estimated to be about 1,200 metres (Pinheiro et al. 1990). The surface area covered by the Uaimapué Formation is larger than the other units of the Roraima Supergroup, extending continuously into Venezuela, Brazil and Guyana (Fig. 14).

According to Reis and Yánez (2001) the Uaimapué Formation is present in two distinct areas on the Brazilian side: 1. Towards Venezuela to the west (Weitepui or Serra do Sol area) where it is dominated by dark tuffaceous sandstones and greenish to reddish ash fall tuffs containing hummocky cross-stratification and mega ripples structures. To the top of the unit, the main geometry of the layers are sigmoidal lobes displaying internal trough cross-stratification (paleocurrents to the NE).

2. Towards Guyana to the east (Maú/Ireng and Uailã River) where it is dominated by lithic arkosic sandstones, pebbly sandstones and quartz sandstones intercalated with ignimbrites and reddish tuffs as observed at Orinduik Falls (Fig. 15). 
In the Cipó Mountain of Brazil, opposite to Kopinang Mountain in Guyana, Costi et al. (1988) described pyroclastics layers corresponding to surge deposits which contain clastic, pumice and acrettionary lapilli fragments. Cipó Mountain was interpreted as a volcanic caldera-type structure (cauldron-type) including a ring dyke (Cipó Dolerite)

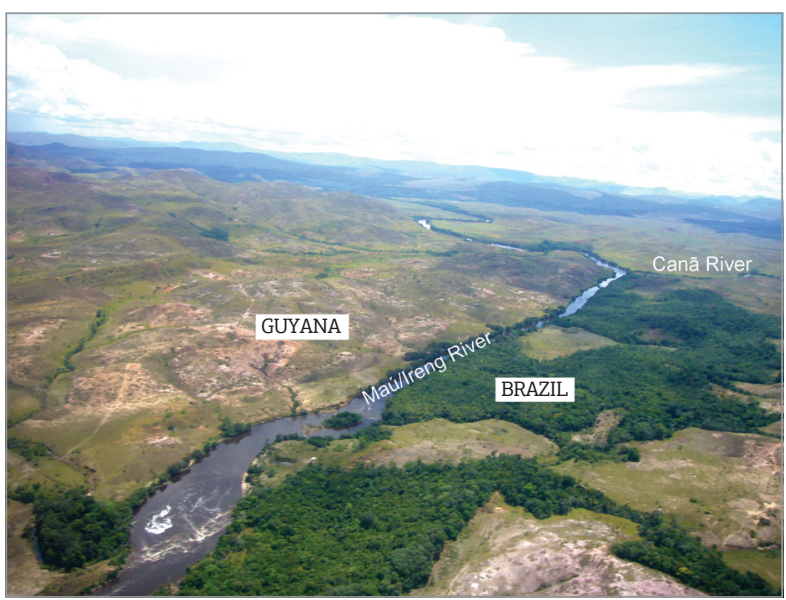

Figure 14. Aerial view of the natural border represented by the Maú-Ireng River between Brazil and Guyana. The area displayed is of the Uaimapue Formation composed mainly of reddish tuffaceous rocks. The aerial photo was taken a few meters south of Orinduik Falls.

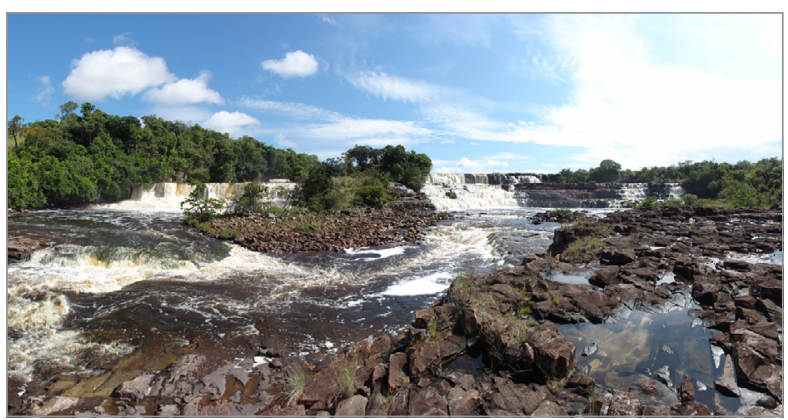

Figure 15. Orinduik Falls, Maú/Ireng River at the border between Brazil and Guyana. of Avanavero age. Pebbly sandstones with quartz and pyroclastic fragments are possibly associated to fanglomerates (intracaldera facies).

In Guyana Keats (1973) has mentioned a series of quartz sandstone with minor shales overlying Unit VII. In turn, Unit VIII grades continously from Unit VII where the first layer of tuffs or tuffaceous sandstones are observed. Based on this observation Units VIII and IX show clear affinities with the Uaimapué Formation in Brazil which is also dominated by pyroclastic layers. This author described an environment similar to a more distal facies of a delta front, intertidal, shoreline, mud-flats, etc. The pyroclastic succession represents a period of volcanism, including airborne, waterlain and reworked materials (volcanogenic).

\section{Matauí Formation}

Mount Roraima (2,734 m) represents the sedimentary unit at the top of the Roraima Supergroup named by Reid (1972) as the Matauí Formation. According to this author, the Formation is also found in the Cuquenán, Yuruani, Ayantepuy and Weitepuy mountains in Venezuela. It is a sedimentary rock unit forming the tabletop mountain, at the triple frontier junction of Brazil with Guyana and Venezuela (Fig. 16).

Near the base of Mount Roraima occurs a sill, informally named "Mount Roraima" (Reis et al. 1990) and partly covered by coarse colluvium deposit. Tate (1930) described greenish tuffs on the sides of the sill, implying its relation to the Uaimapué Formation (Reis \& Yánez 2001). In this way, the gentle transition of the Uaimapué sedimentation to that of the Mataui does not ensure a prolonged timing of deposition between the Formations. There is no field data yet to support a regional unconformity, and the timing and distribution of the Matauí Formation, as proposed by Santos et al. (2003), must remain open-ended.

The Matauí Formation has been described by Pinheiro et al. (1990) as composed of a succession of fine to very fine arkosic sandstones, medium to coarse arenitic quartz, conglomeratic sandstones and conglomerates. The thickness

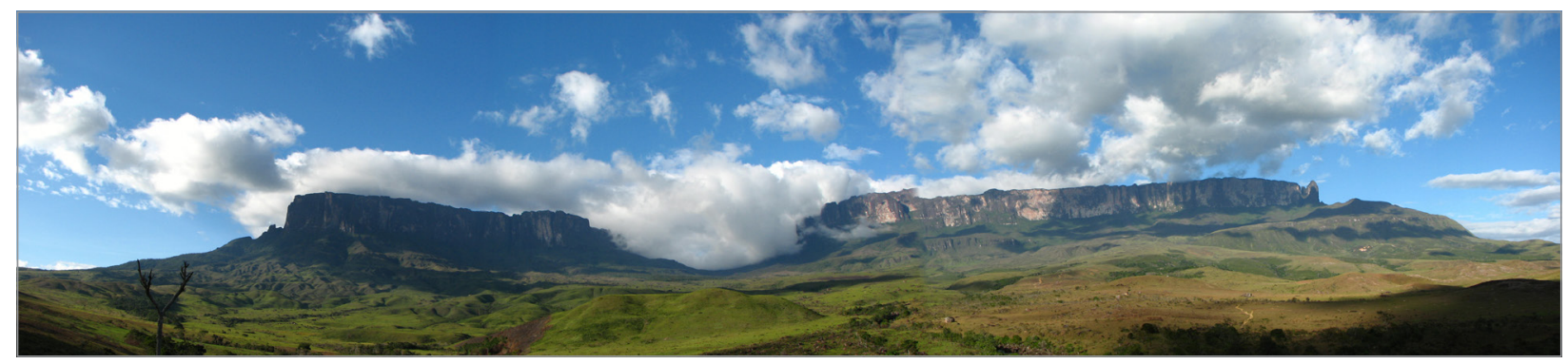

Figure 16. View of the Cuquenán and Mount Roraima Tepuy (from left to right). Both mountains are composed of sedimentary rocks of the Matauí Formation along the triple border junction between Venezuela, Brazil and Guyana. 
of the Formation was estimated to be approximately 600 meters including the talus material at the base of the mountain. Three main palaeoenvironment of depositions of the Matauí Formation were proposed: tidal to shallow marine, aeolian and fluvial, although the latter seems to be more appropiate to define this Formation. It has been considered by various authors to represent two major depositional environments: high energy fluvial environment (Reid 1972) and coastal enviroment marked by wave actions (Ghosh 1981). In Guyana, Keats (1973) has not made any attempts to subdivide the Roraima Supergroup above Unit IX.

The Matauí Formation represents the last stage of the Roraima Supergroup deposition cycle, which corresponds to the final marine regression of the so-called "Verde Sea" (Reis et al. 1990).

\section{FINAL REMARKS}

- The rocks located at the boundary of the Roraima basin suggest an unconformity contact between the Arai Formation and the Surumu/Iwokrama volcanics to the south and with the Transamazonian rocks to the east in Guyana and to the north in Venezuela;

- The stratigraphic integration proposed in this paper based on Reis and Yánez (2001) and Keats (1973) is: the correlation of the Arai Formation with Units I, II, III and IV; the correlation of the Uiramutã, Verde and Pauré Formations with Unit V; the correlation of the Cuquenán Formation with Unit VI; the correlation of the Quinô Formation with Units VII and VIII; the correlation of the Uaimapué Formation with Unit IX and the correlation of the Matauí Formation with Unit X. It is proposed to raise the Roraima Group in Guyana to the status of Supergroup;

- There is a lateral correlation of the Roraima Supergroup throughout the Pakaraima Sedimentary Block across the Venezuela-Brazil-Guyana boundaries where: The marine sedimentary rocks (e.g., Verde and Cuquenán Formations), the acid pyroclastic beds (Uaimapué Formation), diamond-rich braided fluvial systems (Arai Formation) and the dolerite sills remain as excellent marker of this regional correlation;

- Follow up work is recommended to redefine the Quinô and Uaimapué Formations and their stratigraphic relationships in the Roraima Supergroup where it occurs in Brazil, Guyana and Venezuela;

- The Brazil-Guyana Geological and Geodiversity (land-use) Mapping Project constituted a great opportunity of geological integration in both countries and intensification of bilateral partnerships. It also represents an important contribution for the Geological Map of South America, in which Brazil is playing the leading role.

\section{ACKNOWLEDGMENTS}

The authors acknowledge the financial support of the Brazilian Cooperation Agency (ABC) of the External Relationships Ministry and the Guyanese Government. Also the Amerindian communities for allowing access to areas of their reservations (Karasabai and Raposa-Serra do Sol). Thanks to the field crews for logistic during the work on both sides of the border. Lastly to the referees for review and comments of the manuscript, in particular to Dr. Mauricio Ibanez-Mejia (University of Rochester, NY).

\section{REFERENCES}

Barron C.N. 1986. The Roraima Group Along the Western Frontier of Guyana: an interim report and a discussion of the problems involved. Field Conference, Uiramutã, Roraima Territory, Brazil (not published).

Beyer S.R., Hiatt E.E., Kyser K., Drever G.L., MarlattJ.2015. Stratigraphy, diagenesis and geological evolution of the Paleoproterozoic Roraima Basin, Guyana: links to tectonic events on the Amazon Craton and assessment for uranium mineralization potential. Precambrian Research, 267:227-249.

Bouman Q.C. 1959. The Roraima Formation, Northern of Territorio do Rio Branco. Belém, Petrobras/Renor, Relatório Interno 350-A. 17p.

Briceño H.O., Tapia J., Estanga J. 1989. Formación Ichún. Volcanismo Acido del Grupo Roraima. In: Congresso de Geologia, 7., Caracas. Memoria... Caracas, p.52-81.
Brooks W.E. \& Garcia E. 1999. The Carun circular structure An intact Proterozoic caldera, Estado Bolívar, Venezuela. Geological Society of America, 31(7):A-178.

Castro J.C. \& Barrocas S.L.S. 1986. Fácies e ambientes deposicionais do Grupo Roraima. Rio de Janeiro, Petrobrás/Cenpes, 20p.

Costi H.T., Pinheiro S. da S., Reis N.J. 1988. Rochas Piroclásticas da Formação Uailã, Supergrupo Roraima, Território Federal de Roraima. In: SBG, Congresso Brasileiro de Geologia, 35, Belém, Anais, 3:1339-1348.

CPRM. 2016. Programa Geologia do Brasil. Programa Cartografia da Amazônia. Geologia e Recursos Minerais da Folha Ilha de Maracá, NA.20-X-A. Escala 1:250.000. Estado de Roraima. In: Reis N.J., Ramos M.N. (Orgs.). Superintendência Regional de Manaus. Nota Explicativa, 31p. (in press). 
Dreher A.M., Reis N.J., Fraga L.M., Betiollo L.M. 2011. Paleoproterozoic pyroclastic rocks from northern Roraima State, Brazil, Guiana Shield. In: Congreso Latinoamericano de Geología, XIV., Congreso Colombiano de Geologia, XIII., Medellín. Memorias... Medellín, p.243-244.

Gansser A. 1974. The Roraima Problem (South America). Verhandlungen der Naturforschenden Gesellschaften in Basel, 84(1):80-100,

Ghosh S.K. 1981. Geology of the Roraima Group and its Implications. In: Simposium Amazonico, 1., Puerto Ayacucho, Venezuela. Memoria..., p.22-30.

Keats W. 1973. The Roraima Formation Project. 1971-1973 Final Report. Geological Surveys and Mines Dept., Georgetown, Guyana, Report WK 1/73. 68p.

Long D.G.F. 2002. Aspects of Late Palaeoproterozoic fluvial style: the Uairén Formation, Roraima Supergroup, Venezuela. Special Publication of the International Association of Sedimentologists, 33:323-338

Minter L. 2009. Revised Roraima Stratigraphy in Guyana. Defining Preserved Gold Paleoplacer Surfaces. GGMC, Guyana, Internal Conference. 27p.

Nomade S., Knight K.B., Beutel E., Renne P.R., Verati C., Féraud G., Marzoli A., Youbi N., Bertrand H. 2007. Chronology of the Central Atlantic Magmatic Province: implications for the Central Atlantic rifting processes and the Triassic-Jurassic biotic crisis. Palaeogeography, Palaeoclimatology, Palaeoecology, 244:326-344.

Pinheiro S.S., Reis N.J., Costi H.T. 1990. Programa Levantamentos Geológicos Básicos do Brasil. Geologia da Região de Caburaí, Nordeste de Roraima. Escala 1:100.000. Estado de Roraima. DNPM/CPRM. Superintendência Regional de Manaus, 1v., il. 91p.

Reid A.R. 1972. Stratigraphy of Type Area of the Roraima Group, Venezuela. In: Interguiana Conference Geological, 9., Georgetown, Guyana. Memoria..., p.343-353.

Reis N.J. 2009. Monte Roraima, RR - Sentinela de Macunaíma. In: Winge M., Schobbenhaus C., Berbert-Born M., Queiroz E.T., Campos D.A., Souza C.R.G., Fernandes A.C.S. (Eds.). Sítios Geológicos e Paleontológicos do Brasil. 2. ed. Brasília: CPRM. v.2, p.89-98

Reis N.J., Carvalho A.S. 1996. Coberturas sedimentares do Mesoproterozóico do estado de Roraima: avaliação e discussão de seu modo de ocorrência. Revista Brasileira de Geociências, 26(4):217-226.

Reis N.J., Dreher A., Fraga L.M., Scandolara J.E., Betiollo L. 2009. Serra Tepequém, um possível remanescente de uma caldeira vulcânica paleoproterozóica - Estudos preliminares. In: Simpósio de Geologia da Amazônia, XI., Manaus. Anais... SBG-Núcleo Norte.

Reis N.J., Faria M.S.G., Fraga L.M.B., Haddad R.C. 2000a. Orosirian Calc-Alkaline Volcanism and the Orocaima Event in the Northern Amazonian Craton, Eastern Roraima State, Brazil. Revista Brasileira de Geociências, 30(3):380-383.

Reis N.J., Pinheiro S.S. 2004. A Formação Trincheira - um metalotecto diamantífero no norte do Estado de Roraima. In: Congresso Brasileiro de Geologia, 42., Araxá, MG. Anais... SBG. 1 CD-ROM.

Reis N.J.,Pinheiro S.S., Carvalho J.E. 1985. Subdivisão litoestratigráfica da Formação Suapi - Grupo Roraima, Território Federal de Roraima. In: Simpósio de Geologia da Amazônia, 2., Belém, Pará. Anais... SBG, p.408-420

Reis N.J., Pinheiro S.S., Costi H.T., Costa J.B.S. 1990. A Cobertura Sedimentar Proterozóica Média do Supergrupo Roraima no Norte do Estado de Roraima, Brasil: Atribuições aos seus Sistemas Deposicionais e Esquema Evolutivo da sua Borda Meridional. In: Congresso Brasileiro de Geologia, 36., Natal. Anais... SBG, p.66-81.
Reis N.J., Pinheiro S.S.; Costi H.T., Souza Cruz C.E. 1988. A Subdivisão do Grupo Suapi no Contexto do Supergrupo Roraima, Porção Setentrional do T.F. de Roraima. In: Congresso Latino-Americano, 7. Belém, Pará. Anais... SBG, p.389-398.

Reis N.J., Santos J.O.S., McNaughton N.J., Fletcher I. 2000b. Two distinctive Proterozoic Sedimentary covers in the Northern Amazonian Craton, Roraima State, Brazil. In: International Geological Congress, 31., Rio de Janeiro. Expanded Abstract.

Reis N.J., Teixeira W., Hamilton M.A., Bispo-Santos F., Almeida M.E. D'Agrella-Filho M.S. 2013. Avanavero Mafic Magmatism, a Late Paleoproterozoic LIP in the Guiana Shield, Amazonian Craton: U$\mathrm{Pb}$ ID-TIMS baddeleyite, Geochemical and Paleomagnetic Evidence. Lithos, 174:175-195.

Reis N.J., Yánez G. 2001. O Supergrupo Roraima ao longo da Faixa Fronteiriça entre Brasil e Venezuela (Santa Elena de Uairén - Monte Roraima). In: Reis N.J., Monteiro M.A.S. (Eds.). Contribuições à Geologia da Amazônia. Manaus: SBG/Núcleo Norte. v.2. p.115-147.

Santos J.O.S. 1985. A Subdivisão Estratigráfica do Grupo Roraima. In: Simpósio de Geologia da Amazônia, 2., Belém, PA. Anais... SBG. p.421-431.

Santos J.O.S., D’Antona R.J.G. 1984. A Formação Arai e a subdivisão do Grupo Roraima. In: Congresso Brasileiro de Geologia, 33., Rio de Janeiro, RJ. Anais... SBG. p.1162-1173.

Santos J.O.S., Hartmann L.A., Faria M.S.G., Riker S.R.L., Souza M.M., Almeida M.E., McNaughton N.J. 2006. A compartimentação do Cráton Amazonas em Províncias: avanços ocorridos no período 2000-2006. In: Simpósio de Geologia, 9., Belém. Resumo Expandido.. SBG-Núcleo Norte. 1 CD-ROM.

Santos J.O.S., Potter P.E., Reis N.J., Hartmann L.A, Fletcher IR McNaughton N.J. 2003. Age, source and Regional Stratigraphy of the Roraima Supergroup and Roraima-like Sequences in Northern South América, based on U-Pb Geochronology. Geological Society of America Bulletin, 115(3):331-348.

Tassinari C.G.C. Macambira M.J.B. 2004. A evolução tectônica do Cráton Amazônico. In: SBG (Ed.). Geologia do Continente Sul-Americano - Evolução da Obra de Fernando Flávio de Almeida. São Paulo: Ed. Beca. Capítulo XXVIII, p.471-486.

Tate G.H.H. 1930. Notes on the Mount Roraima region. Geographic Review, 20(1):53-68.

Walker R.G. 1984. Turbidites and Associated Coarse Clastic Deposits. In: Walker R.G. (Ed.). Facies Models. 2. ed. Canada: Geoscience Canada Reprint Series 1. p.171-188.

Wankler F.L. 2001. Caracterização geométrica e arquitetural dos corpos fluviais mesoproterozóicos da Formação Arai (Supergrupo Roraima), nordeste do Estado de Roraima, Brasil. São Leopoldo, RS. Dissertação de Mestrado, Universidade do Vale dos Sinos, São Leopoldo, 180p.

Wankler F.L., Paim P.S.G., Garcia A.J.V. 2003. Arquitetura deposicional e concentração de minerais pesados na Formação Uiramutã, estado de Roraima, Brasil. In: Paim P.S.G., Faccini U.F., R.G. Netto (Eds.) Geometria, arquitetura e heterogeneidades de corpos sedimentares Estudo de casos. FINEP-Petrobras: São Leopoldo. p.207-223.

Yánez G.A. 1972. Geología del Área de Santa Elena de Uairén (Mapa de Interpretación de $12.000 \mathrm{~km}^{2}$ en escala 1:250.000). In: Conferencia Geologica Inter-Guayanas, 9., Ciudad Guayana, Venezuela. Memoria... p.660-667

Yánez G.A. 1977. Província Geológica de Roraima, Geología Estructural e Geomorfologia de su parte Suroriental, Venezuela. In Congresso de Geologia, 5., Caracas, Venezuela. Memoria... p.845-854.

Available at www.sbgeo.org.br 